\title{
Oral and Dental Hygiene of Primary School Children at Banha district, Qalubia Governorate, Egypt
}

\author{
Aml A. Salama MD ${ }^{1}$, Heba M. Hassan, MBBCh ${ }^{2}$, Safa H. Alkalash, MD $^{1 *}$ \\ ${ }^{1}$ Family Medicine Department, Faculty of Medicine, Menoufia University, Egypt. \\ 2* Ministry of Health, Egypt.
}

\begin{abstract}
:
Background: Increasing levels of tooth decay in children and adolescents have been particularly noticeable in developing countries over the past two decades, especially when compared to developed countries. Little is known about oral health behavior of children from developing countries. Objectives: To assess oral and dental hygienic practices of primary school children, and determine the factors affecting them in Banha district, Qalubia Governorate. Methods: In this cross-sectional study, 408 children aged 9-11 years were surveyed using a self-administered questionnaire to identify their socio-demographic characteristics and examine their oral hygiene practice. An informed written consent was obtained from parents of each participant. The children were subjected to oral and teeth examination. Results: Dental examination revealed that $68 \%$ of the participants had decayed teeth and $6.8 \%$ had filled teeth, which was related to inappropriate healthy practice such as proper teeth brushing. Age and socioeconomic status of studied children constituted statistically significant difference, as dental caries was more observable among younger groups $(9.93 \pm 0.86)$ and among children from higher socioeconomic status. Conclusion: Children maintenance of oral health was improper and significantly increased their exposure to dental caries.
\end{abstract}

Keywords: Children, Dental, Egypt, Hygiene, Practice.

\section{Introduction:}

Oral health means more than good teeth. It is integral to general health and essential for well-being. Many general diseases have oral manifestations that increase the risk of oral disease, which, in turn, is a risk factor for a number of general health conditions. ${ }^{(1)}$ Despite significant improvements in the oral health of populations in several countries, global oral health problems still persist. Oral disease demonstrates a strong correlation to socioeconomic status. Major risk factors relate to unhealthy lifestyles (i.e. poor diet, malnutrition and poor oral hygiene and use of tobacco and alcohol), nd limited availability and accessibility to oral health services. ${ }^{(2)}$ About $\quad 90 \%$ of schoolchildren worldwide and most adults have experienced dental caries, with the disease being most prevalent in Asian and Latin American countries. ${ }^{(2)}$ In Egypt, 74\% of the children have dental caries. ${ }^{(3)}$ This could be attributed to several factors chief among which lack of oral health awareness and over consumption of refined carbohydrates. Children who suffer from poor oral health are 12 times more likely to have restricted-activity days than those who do not. ${ }^{(4)}$

Nowadays, various types of oral health maintenance material have been used, and countless number of dental health information programs have been conducted in schools and other settings. However, these efforts did not succeed in influencing oral health; hence, the attainment of good

*Corresponding author: E-mail: dr_safa4@yahoo.com 
oral health is a function of the awareness about good dietary habits and oral hygiene practices. $^{(5)}$

Childhood is the period of the most extensive change in life. It is widely recognized that good oral health practices are necessary from a young age to ensure positive long-term dental health and hygiene. ${ }^{(6)}$ Good oral health can be effectively achieved and controlled through a combination of community, professional and individual action. ${ }^{(1)}$

Over the past two decades, increasing levels of tooth decay in children and adolescents have been particularly noticeable in developing countries over the past two decades, especially when compared to developed countries. ${ }^{(7)}$ Little is known about oral health attitudes and behaviors of children from developing countries in comparison to developed countries. ${ }^{(8,9)}$ This study, therefore, was conducted to assess oral and dental hygiene of primary school children.

\section{Method:}

Research Design: The research design was an analytic cross sectional study.

Study Setting and Time: Three primary schools at Banha district were selected out of 109 schools using simple randomization technique, and their ratio distribution was one urban to two rural governmental schools (as total number of the urban schools was 18 schools while rural schools were 91 schools). The study was conducted within a period of 14 months, from 1 June 2018, until end of August 2019.

Study Sample: Target students were $4^{\text {th }}, 5^{\text {th }}$ and $6^{\text {th }}$ grade students (9-11 years old students). The sample size was calculated by using Epi Info. Version 7 to include 408 primary school students (based on excellent practice of young children oral hygiene from previous literatures at average of $60 \%$ ) (10) and 72929 as a total number of registered primary schools students (study population) at Banha district in academic year 19181919.

The study sample was selected using simple random sampling technique and was proportionally allocated according to the total number of children in selected schools. Accordingly, 318 students were chosen from rural schools and 90 students from Banha city schools.

Study Variables: Main study variables were:

- Independent variables including, sociodemographic character of the studied group which include sex and age of students, age of mothers, socio-economic levels, and parents' education and occupation.

- Dependent variables includes, oral health status, practice of the participants. 
Tools for data Collection and Procedure:

Tools included: A questionnaire and a checklist for dental examination.

A-Socio economic Status Scale ${ }^{(11)}$ : Using help from schools' administration, socio-economic scales were sent to be completed by parents. They comprised seven domains with a total score 84 of these domains. SES (socio-economic status) was classified into three levels depending on the quartiles of the score calculated: those with score range from 19- 38 (low), from 38- 57 (middle) and from 57 84 (high social class).

B-Self-administered

Structured

Questionnaire: Validity of the questionnaire was tested by being submitted to a panel of three experts. The experts were professors in Family medicine, Community medicine, and Dental medicine. The preliminary items were revised by the experts to determine whether the items were relevant for assessment. The experts were asked to evaluate individual items in relation to its relevance and appropriateness then rate items on a four point scale as the following:

-4-Adequate (simple, relevant and clear)

-3-Adequate but needs minor revision
- 2-Needs major modification

-1-Not so adequate (could be omitted)

Content validity index (CVI) is the percentage of total item that was rated by experts, which was either 3 or 4 . CVI denote valid content when it is $\geq 80 \%{ }^{(12)}$. CVI of the designed questionnaire was calculated and it was $95 \%$, therefore it was considered a valid tool and was used in data collection. Reliability of the questionnaire was calculated using SPSS version 20 using Cronbach's alpha which was $(\mathrm{r}=0.8)$. Hence, the questionnaire reliability was confirmed.

Participants were subjected to the predesigned questionnaire and their oral health hygiene was assessed. The questionnaire consisted of 15 questions to assess child practice regarding oral hygiene which included items pertinent to brushing practice (frequency, duration and timing), the parents' role in participants' oral hygiene, and dental clinic visits among other factors.

C- Oral and Dental Examination: The children also were subjected to oral examination, which was conducted in the school clinic with sterile dental equipment by a dentist to detect any dental problem. Examination findings of each student were recorded in a checklist. Finally, according to dental examination findings of the 
children, participants were classified into two groups (a group had dental carries and another had no dental carries).

A one-month pilot study on 20 children was conducted. Through this pilot study, the questionnaire was pretested and time needed to fill it out was determined. Oral and dental examination of the students by a dentist was conducted to gauge its duration. Students who were included in the pilot study were excluded from the main study.

Procedure of the study: The data were collected by attending the schools four times per week for the duration of three months. Children were selected from grades four, five and six to be able to understand and fill the questionnaire. With help of school administration, children delivered socioeconomic scales to their parents to be completed at home.

The practice survey was distributed in classrooms on available free time, mainly during break. The researcher explained each question in easy, understandable manner to the students. Each question was read aloud by the researcher to the students and they answered it in the questionnaire paper. Children were then examined by a dentist who registered the number of carious teeth and the number of filled teeth for each student. The children who needed dental treatment were referred to health insurance clinic related to their residence area.
Data Management: The data were tabulated and analyzed using SPSS (Statistical package for social science) version 20 to obtain:

I-Descriptive statistics for the data that were in the form of:

1. Mean and standard deviation $( \pm S D)$. Median and inter-quartile range (IQR) for quantitative data.

2. Frequency and percentages for qualitative data.

II-Analytical statistics: In the statistical comparison between the different groups, the significance of difference was tested using Chi-test $\left(\chi^{2}\right)$ or Fisher exact test to compare two independent qualitative variables. $\mathrm{P}$ value less than 0.05 was considered statistically significant.

Ethical Consideration: The study was approved by the ethical committee of the faculty of medicine, Menoufia University. An official permission letter was obtained from the relevant authorities and was directed to Educational Administration in Banha district. Then written consents were granted by the headmasters of the schools where the study was conducted.

After illustration of study purposes to the parents of students, and with help of school administration, parents were encouraged to give well informed consent to permit study conduction. Written consents emphasized that all data collected 
was strictly confidential, and that data were used for scientific purposes to detect the students' dental hygiene. It also stated that participants had the right to refrin from filling out the questionnaire.

\section{Results:}

The mean age of students $( \pm$ SD) was $10.01( \pm 0.85)$ years and the mean age of mothers was $37.22( \pm 5.32)$ years. Female to male ratio was equal. About $30 \%$ of fathers had professional jobs. About half of mothers were housewives (53.9\%). Number of family members was more than five members in $74.5 \%$ of students.

Average household income per month was described by caregivers as being enough in $63 \%$ of the studied group .Crowding index (family members' number per room) was less than three per room in (70.3\%) of studied group. Written information was the preferable for $67.2 \%$ of students for understanding health information (Table 1).

After teeth examination, $39.2 \%$ of students were having 1-2 decayed teeth, $28.4 \%$ of them were having three or more decayed teeth and $93.1 \%$ of students had no filled teeth (Table 2).

More than two thirds of the studied group $(69.4 \%)$ usually clean their teeth, of them $65.7 \%$ clean their teeth twice or more per day. The most commonly used material for teeth cleaning was tooth brush and paste
(99.6\%). They clean their teeth at the morning according to $(74.9 \%)$ of them. The time needed for teeth cleaning was more than two minutes according to $(39.9 \%)$ of them. Parents did not watch the child but gave advice only according to $(68.1 \%)$ of them (Table 3).

There was a statistically significant difference between practice of children and their sex as female students were practicing teeth cleaning more than males while there were no statistically significant differences in oral hygiene with reference to their age, mothers' age, SES, level of parents' education or occupation ( Table 4).

There was a statistically significant difference between oral health status of children and age of students, as dental caries was increased with younger age of the studied group (9.93 \pm 0.86$)$. Dental caries was higher among higher\& moderate socio economically students. Also it increased among children whose highly educated mothers. While there was no statistically significant differences between oral health status of children and students' sex, age of mother, level of father education, mother's or father's occupation (Table 5).

\section{Discussion:}

In the current study, about $68 \%$ of the subjects were having one or more carious teeth, while $6.8 \%$ were having one or more filled teeth, which is similar to a study done 
by Assiut governorate, Egypt, who reported that $78.4 \%$ had one or more carious teeth while only $17.5 \%$ had one or more filled teeth. $^{(13)}$ The results however contrast a study done by in North Jordan who reported that about $75 \%$ of the sample reported having one or two carious teeth while (91\%) reported having one or two filled teeth. ${ }^{(10)}$ They also contrast another study done by in which dental caries was observed in $37.7 \%$ children and the prevalence of dental caries in the 10 to 12 years old children was lesser as compared to 5-6 year old children. ${ }^{(14)}$

As regards to practice of pupils for dental health care, $65.7 \%$ of them clean their teeth twice or more per day, which partly agrees with a study ${ }^{(15)}$ and matches what was observed in some industrialized countries of east Europe in which $58.3 \%$ of children performed the recommended practice of brushing the teeth twice a day. (16-17) This finding however was higher than a study, which showed a result of $(33.8 \%)$ (13) and another study who reported $38.5 \%$ correct practice of teeth brushing. ${ }^{(18)}$ On the other hand, in a study ${ }^{(14)}$, the majority of the subjects brush their teeth at least once a day, but a significant number (19\%) did not brush even once a day, indicating the lack of awareness about oral hygiene. In yet another study, (72\%) subjects brushes their teeth once daily. ${ }^{(19)}$ The percentage of the children who brushed their teeth twice per day was $(65.7 \%)$ and it was supported by parents by almost the same percentage $(68.1 \%)$ in which they advised and never watched their child during tooth brushing. Lack of both parental and child oral health education might also explain these findings. This result is in accordance with similar results in two studies conducted in Jordan $\left({ }^{10)}\right.$ and Chennai (India) ${ }^{(15)}$ with percentages $(59 \%)$ and $61.7 \%$ respectively.

More than one third $(31,1 \%)$ of children stated that there was no follow up from their parents regarding oral hygiene, which is similar to a study in which nearly $34.5 \%$ of the children stated that their parents never guide them about good oral hygiene practices. ${ }^{(14)}$ Also, about $40 \%$ of the children spent more than two minutes cleaning their teeth, which is nearly similar to another study ${ }^{(20)}$.

Children practice brushing in the morning (74.9\%) and before going to sleep $(72.1 \%)$ whereas in several studies $(21,13,15,14)$, brushing happened primarily in the morning. This is in contrast to the study conducted on Jordanian children (10) in which brushing majorly happens before going to sleep.

Nearly all children who brush their teeth (99.6\%) used toothbrushes and toothpaste for cleaning their teeth. The use of other recommended oral hygiene methods such as mouthwash \& floss was found to be absent. 
This also could be attributed to the lack of oral health education and/or the cost of such tools. Similar results were reported by other studies, who reported utilization of toothbrush and paste by predominant

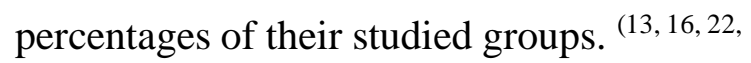
23) Use of other locally available teeth cleaning agents that are applied on fingers, reflecting a negligent attitude towards oral hygiene, were reported in $19.8 \%$ a study while the majority of the subjects $(87.8 \%)$ used tooth brush with tooth paste as oral hygiene aid. ${ }^{(19)}$ In an Indian study, $81 \%$ used both toothbrush and toothpaste. ${ }^{(24)}$

These results are not in agreement with that reported by a study in Chennai where in their study sample some of the children resorted to the use of charcoal as a medium to brush their teeth than the toothbrush. This could be probably due to lack of awareness or affordability for tooth brush and paste ${ }^{(25)}$ \& study conducted in Karachi by Mirza et al.,2011 where only $49 \%$ subjects used tooth brush and tooth paste. (26)

There was a significant difference between oral health status and participants' socio-economic status. Dental caries was higher among high and middle socioeconomic class students, which agrees with a study (27) that reported that a highly significant association between oral hygiene and socio-economic status in which the largest proportion of subjects who had good oral hygiene belonged to lower socioeconomic status whereas subjects with higher socioeconomic status $(45 \%)$ were found to have poor oral hygiene. Another study was conducted in Brazil (28) also reported that school children who belonged to families whose income was lower than one minimum wage were 1.89 times more likely to have dental problems, as household environments are an important social determinant of children's oral health. Conclusion: Children's teeth cleaning practice needs to be reinforced. Frequency of dental caries was higher among younger children who belong to high or middle socio-economic class. So researchers recommend that more training session should be conducted to correct improper practice of oral and dental hygiene among school children in an attempt to prevent and control dental diseases and regular dental check-up (screening program) needed to be conducted for school children. Acknowledgements: Researchers would like to express great and deep gratitude and sincere appreciation to all participants who agree to participate in this study.

\section{No fund:}

\section{No conflict of interest:}




\section{References:}

1. Petersen P.: The World Oral Health Report Continuous improvement of oral health in the $21^{\text {st }}$ century The approach of the WHO Global Oral Health Programme. Community Dent Oral Epidemiol ; 2003,31 (1) :3-23.

2. Petersen $\mathrm{P}$, Bourgeois D, Ogawa $\mathrm{H}$, et al.: The global burden of oral diseases and risks to oral health. Bull World Health Organ;2005, 83(9):661-669 .

3. Abbass M, Mahmoud S, El moshy S. et. The prevalence of dental caries among Egyptian children and adolescences and its association with age, socioeconomic status, dietary habits and other risk factors. A cross-sectional study. F1000Research, $\quad 8, \quad 8$. doi:10.12688/f1000research. 2019, 17047.1

4. Bingaman J, Feingold R : Oral Health Dental Disease is a Chronic Problem among Low-Income Populations. Washington, DC. Report to Congressional Requesters . US General Accounting Offices.2000.

5. Grewal N, Kaur M.: Status of oral health awareness in Indian children as compared to Western children: A thought provoking situation. J Indian Soc Pedod Prev Dent ; 2007,25:15-9.

6. Mathur A, Gupta, T : oral health attitude knowledge behavior and consent towards dental treatment among school children. Jou rnal of orofacial research; 2011, 1(1):6-10.

7. Ojahanon PI, Akionbare O, Umoh AO: The oral hygiene status of institution dwelling orphan $\mathrm{s}$ in Benin City, Nigeria. Nigerian journal of clinical practice. 2013(1):41-4 .

8. Suprabha BS, Rao A, Shenoy R,et al.: Utility of knowledge, attitude, and practice survey, and prevalence of dental caries among 11- to 13-year- old children in an urban community in India. Global health action ;2013,6:20750.

9. Diwan S, Saxena, V, Bansal, S, et al. Oral Health: Knowledge and Practices in Rural Community. Indian J Comm Health.2011,22:29-33.

10. Al- Omiri M, Board, J, Al- Wahadni, A, et al.: Oral health attitudes, knowledge and behavior among school children in North Jordan. Journal of Dental $\begin{array}{lll}\text { Education;2005, } & 70 \quad \text { (2):179-87 }\end{array}$ .Available from http//www.indianow.org.cited on 14/11/10

11. El-Gilany A, El-Wehady A, El-Wasify M: Updating and validation of the socioeconomic status scale for health research in Egypt. East Mediator Health Journal 2012; 18(9):962-968.

12. Schilling L, Diaxon J, Knafl K, Grey M, Ives B, Lyne M (2007): Determining 
content validity of a self-report instrument for adolescents using a heterogonous expert panel. Nurs Res. 2007; 56 (5):361-6.

13. Ahmed S, Soliman A, Elmagrabi N, Sayed S (2015): Oral Health Knowledge, Attitude and Practice among Primary School Children In Rural Areas of Assiut Governorate. Egyptian Journal of Community Medicine; 33(4).

14. Kumar R, Joshi D.: Awareness of dental hygiene amongst the primary school children of low socio-economic strata. Int $\mathbf{J}$ Contemp Pediatrics, 2017, 4(1), 28-35.

15. Priya M, Kanagharekha Devdas1, DeeptiAmarlal, et al.: Oral health attitudes, knowledge and practice among school children in Chennai, India. Journal of Education and Ethics in Dentistry ; 2013, $3: 26-33$

16. WHO: Oral Health Status in rural child population: Promotional and Interventional Strategies. A GOI-WHO Collaborative Programme 2006-07 .2012.

17. Chen M, Andersen R, Barmes D, et al.: Comparing oral health care systems: A second international collaborative study. Geneva: WHO; 1997.

18. Harikiran A, Pallavi S, Hariprakash S, et al.: Oral health-related KAP among 11-to 12year-old school children in agovernmentaided missionary school of Bangalor city. Indian Journal of Dental Research; 2008,19 (3):236-42.

19. Mishra P, Solanki J, Choudhar R, Sharma C, Sharma P, Shah D.: Attitude towards oral hygiene among different socio-economic groups in Jaipur city, Rajasthan. Clujul Medical, 92(1), 79-82.

20. Kolawole K, Oziegbe E , Bamise C: Oral hygiene measures and the periodontal status of school children. International journal of dental hygiene; 9(2), 143-148.

21. Jabeen C, Umbreen G.: Oral Hygiene: Knowledge, Attitude and Practice among School Children, Lahore. J Liaquat Uni Med Health Sci. 2017;16(03):176-80.

22. Punitha V and Sivaprakasam P. (2011): Oral hygiene status, knowledge, attitude and practice of oral health among rural children of Kanchipuram District. Indian J Multidiscip Dent; 1:115-8.

23. Al Subait A, Alousaimi M, Geeverghese A, et al.: Oral health knowledge, attitude and behavior among students of age 10-18 years old attending Jenadriyah festival Riyadh; a cross-sectional study. The Saudi Journal for Dental Research; 2016,7(1): 4550.

24. Handa S, Prasad S, Rajashekharappa C, et al.: Oral Health Status of Rural and Urban Population of Gurgaon Block, Gurgaon District, Using WHO Assessment Form through Multistage Sampling Technique. J Clin Diagn Res;2016,10:ZC43-ZC51.

25. Mahesh Kumar P, Joseph T, Varma R: Oral health status of 5 years and 12 years school going children in Chennai city. An epidemiological study. J Indian Soc Pedo Prev Dent; 2019,23: 17-22.

26. Mirza B, Syed A, Izhar F, Ali K.: Oral health attitudes, knowledge, and behavior 
amongst high and low socioeconomic school going children in Lahore, Pakistan.

Pak Oral Dent J ;2011, 31: 396-401.

27. Bodhale P, Karkare S, Khedkar S: Knowledge and attitude of parents toward oral health maintenance and treatment modalities for their children. Journal of dental research and review; 2014,1:24-27.

28. Paula J, Ambrosano G, Mialhe F: The impact of social determinants on schoolchildren's oral health in Brazil. Braz Oral Res;2015,29:1-9.

Table (1): Socio demographic Characters of the studied group:

\begin{tabular}{|c|c|c|}
\hline & No (408) & $\%$ \\
\hline $\begin{array}{ll}\text { Sex } & \\
\text { - } & \text { Male } \\
\text { - Female }\end{array}$ & $\begin{array}{l}204 \\
204\end{array}$ & $\begin{array}{l}50.0 \\
50.0\end{array}$ \\
\hline Age of mother: $\quad$ Mean \pm SD (Range) & \multicolumn{2}{|c|}{$37.22 \pm 5.32(9-56)$} \\
\hline Age of student: $\quad$ Mean \pm SD (Range) & \multicolumn{2}{|c|}{$10.01 \pm 0.85(6-11)$} \\
\hline $\begin{array}{l}\text { Mother's occupation } \\
\text { - Housewife } \\
\text { - } \text { Farmer } \\
\text { - } \text { Cleric } \\
\text { - } \text { Employer } \\
\text { - } \text { Physicician, teacher or engineer }\end{array}$ & $\begin{array}{l}220 \\
11 \\
14 \\
35 \\
22 \\
106 \\
\end{array}$ & $\begin{array}{l}53.9 \\
2.7 \\
3.4 \\
8.6 \\
5.4 \\
26.0\end{array}$ \\
\hline $\begin{array}{l}\text { Father's occupation } \\
\text { - Un employer } \\
\text { - Farmer or worker } \\
\text { - } \text { Cleric } \\
\text { - Employer } \\
\text { - } \text { Business man } \\
\text { - Physician, teacher or engineer }\end{array}$ & $\begin{array}{l}7 \\
48 \\
31 \\
94 \\
104 \\
124\end{array}$ & $\begin{array}{l}1.7 \\
11.8 \\
7.6 \\
23.0 \\
25.5 \\
30.4\end{array}$ \\
\hline $\begin{array}{l}\text { Number of family members } \\
\cdot \quad>5 \\
\cdot \quad<5\end{array}$ & $\begin{array}{l}304 \\
104\end{array}$ & $\begin{array}{l}74.5 \\
25.5\end{array}$ \\
\hline $\begin{array}{l}\text { Average household income per month } \\
\text { - Enough } \\
\text { - Not enough } \\
\text { - } \text { More than enough } \\
\end{array}$ & $\begin{array}{l}257 \\
23 \\
128 \\
\end{array}$ & $\begin{array}{l}63.0 \\
5.6 \\
31.4 \\
\end{array}$ \\
\hline $\begin{array}{c}\text { Crowding index } \\
\text {. } \quad<3 \text { /room } \\
. \quad>3 \text { /room }\end{array}$ & $\begin{array}{l}287 \\
121\end{array}$ & $\begin{array}{l}70.3 \\
29.7\end{array}$ \\
\hline $\begin{array}{l}\text { How can you understand health information } \\
\text { - Written information } \\
\text { - } \mathrm{TV} / \text { radio }\end{array}$ & $\begin{array}{l}274 \\
134\end{array}$ & $\begin{array}{l}67.2 \\
32.8\end{array}$ \\
\hline $\begin{array}{l}\text { Socioeconomic status } \\
\text { - High } \\
\text { - Middle } \\
\text { - Low }\end{array}$ & $\begin{array}{l}175 \\
218 \\
15\end{array}$ & $\begin{array}{l}42.9 \\
53.4 \\
3.7\end{array}$ \\
\hline
\end{tabular}


Table (2): Characteristic features of the studied group according to dental examination

\begin{tabular}{|l|l|l|}
\hline Dental health status & No (408) & \% \\
\hline Decayed teeth & & \\
- None & 132 & 32.4 \\
- One-two & 160 & 39.2 \\
- Three or more & 116 & 28.4 \\
\hline Filled teeth & & \\
- None & 380 & 93.1 \\
- One & 18 & 4.4 \\
- Two & 7 & 1.7 \\
- Three & 3 & 0.7 \\
\hline
\end{tabular}

Table (3) Practice of the studied group of the children regarding cleaning teeth

\begin{tabular}{|c|c|c|}
\hline Practice & No (408) & $\%$ \\
\hline $\begin{array}{l}\text { Do you clean your teeth } \\
\text { - Yes } \\
\text { - No. }\end{array}$ & $\begin{array}{l}283 \\
125\end{array}$ & $\begin{array}{l}69.4 \\
30.6\end{array}$ \\
\hline $\begin{array}{l}\text { How many times }(\mathbf{2 8 3}) \\
\text { - } \quad<\text { once per day } \\
\text { - Once per day } \\
\text { - } \geq \text { Twice per day. }\end{array}$ & $\begin{array}{l}41 \\
56 \\
186\end{array}$ & $\begin{array}{l}14.5 \\
19.8 \\
65.7\end{array}$ \\
\hline $\begin{array}{l}\text { Material used for teeth cleaning (283) } \\
\text { - Tooth brush \& tooth paste } \\
\text { - Mouth wash } \\
\text { - Siwaak } \\
\text { - Thread for teeth cleaning } \\
\text { - } \text { More than one }\end{array}$ & $\begin{array}{l}282 \\
0 \\
0 \\
0 \\
1\end{array}$ & $\begin{array}{l}99.6 \\
0.0 \\
0.0 \\
0.0 \\
0.4\end{array}$ \\
\hline $\begin{array}{l}\text { When do you clean your teeth } \mathbf{( 2 8 3 )} \\
\text { - At the morning } \\
\text { - After eating } \\
\text { - Before going to sleep } \\
\text { - At any time }\end{array}$ & $\begin{array}{l}212 \\
86 \\
204 \\
2\end{array}$ & $\begin{array}{l}74.9 \\
30.4 \\
72.1 \\
0.7\end{array}$ \\
\hline $\begin{array}{l}\text { What time needed for cleaning teeth: } \mathbf{( 2 8 3 )} \\
\text { - <One minute } \\
\text { - One minute } \\
\text { - Two minutes } \\
\text { - } \text { More than two minutes }\end{array}$ & $\begin{array}{l}5 \\
50 \\
115 \\
113\end{array}$ & $\begin{array}{l}1.8 \\
17.7 \\
40.6 \\
39.9\end{array}$ \\
\hline $\begin{array}{l}\text { Parents follow the child during cleaning teeth: } \\
\text { - Parents follow the child } \\
\text { - Not watch the child but give advice only } \\
\text { - No interest from parents }\end{array}$ & $\begin{array}{l}3 \\
278 \\
127\end{array}$ & $\begin{array}{l}0.7 \\
68.1 \\
31.1\end{array}$ \\
\hline
\end{tabular}


Table (4): Comparison of oral health status regarding socio demographic characters

\begin{tabular}{|c|c|c|c|c|c|c|}
\hline \multirow[b]{2}{*}{$\begin{array}{ll}\text { Sex } & \\
\text { - } & \text { Male } \\
\text { - } & \text { Female }\end{array}$} & \multicolumn{2}{|c|}{$\begin{array}{l}\text { Good oral } \\
\text { Hygiene group } \\
(\text { No Dental } \\
\text { Caries ) } \\
\text { No=133 }\end{array}$} & \multicolumn{2}{|c|}{$\begin{array}{l}\text { Bad } \begin{array}{r}\text { oral } \\
\text { hygiene group } \\
\text { (Dental caries) }\end{array} \\
\text { No }=275\end{array}$} & \multirow{2}{*}{$\begin{array}{l}\begin{array}{l}\text { Statistical } \\
\text { test } \\
\mathbf{X}^{\mathbf{2}}\end{array} \\
0.90\end{array}$} & \multirow{2}{*}{$\begin{array}{l}\mathbf{P} \\
\text { value } \\
0.34\end{array}$} \\
\hline & $\begin{array}{l}71 \\
62\end{array}$ & $\begin{array}{l}53.4 \\
46.6\end{array}$ & $\begin{array}{l}133 \\
142\end{array}$ & $\begin{array}{l}48.4 \\
51.6\end{array}$ & & \\
\hline $\begin{array}{l}\text { Age of mother } \\
\text { - Mean } \pm \text { SD }\end{array}$ & \multicolumn{2}{|c|}{$37.19 \pm 5.02$} & \multicolumn{2}{|c|}{$37.23 \pm 5.47$} & $0.08^{* * *}$ & 0.94 \\
\hline $\begin{array}{l}\text { Age of student } \\
\quad \text { Mean } \pm \text { SD }\end{array}$ & \multicolumn{2}{|c|}{$10.17 \pm 0.83$} & \multicolumn{2}{|c|}{$9.93 \pm 0.86$} & $2.58^{* * *}$ & $0.01 *$ \\
\hline $\begin{array}{l}\text { Level of mother education } \\
\text { - Illiterate } \\
\text { - Primary or preparatory } \\
\text { - Secondary } \\
\text { - University } \\
\end{array}$ & $\begin{array}{l}3 \\
29 \\
58 \\
43\end{array}$ & $\begin{array}{l}2.3 \\
21.8 \\
43.6 \\
32.3 \\
\end{array}$ & $\begin{array}{l}9 \\
50 \\
86 \\
130 \\
\end{array}$ & $\begin{array}{l}3.3 \\
18.2 \\
31.3 \\
47.3 \\
\end{array}$ & 9.51 & $0.023 *$ \\
\hline $\begin{array}{l}\text { Level of father education } \\
\text { - Illiterate } \\
\text { - Primary or preparatory } \\
\text { - Secondary } \\
\text { - University } \\
\end{array}$ & $\begin{array}{l}5 \\
23 \\
50 \\
55\end{array}$ & $\begin{array}{l}3.8 \\
17.3 \\
37.6 \\
41.4\end{array}$ & $\begin{array}{l}8 \\
44 \\
77 \\
146\end{array}$ & $\begin{array}{l}2.9 \\
16.0 \\
28.0 \\
53.1\end{array}$ & 5.45 & 0.14 \\
\hline $\begin{array}{l}\text { Mother's Job } \\
\text { - House wife } \\
\text { - Un employer } \\
\text { - Employer } \\
\text { - Professional }\end{array}$ & $\begin{array}{l}74 \\
9 \\
13 \\
27\end{array}$ & $\begin{array}{l}55.6 \\
6.8 \\
9.8 \\
27.8\end{array}$ & $\begin{array}{l}146 \\
16 \\
22 \\
91\end{array}$ & $\begin{array}{l}53.1 \\
5.8 \\
8.0 \\
33.1\end{array}$ & 5.26 & 0.15 \\
\hline $\begin{aligned} \text { Father's Job } \\
\text { - Un employer } \\
\text { - Employer } \\
\text { - } \text { Professional } \\
\end{aligned}$ & $\begin{array}{l}72 \\
37 \\
69 \\
\end{array}$ & $\begin{array}{l}20.3 \\
27.8 \\
51.9\end{array}$ & $\begin{array}{l}59 \\
57 \\
159 \\
\end{array}$ & $\begin{array}{l}21.4 \\
20.7 \\
57.8\end{array}$ & 21.27 & $0.001^{*}$ \\
\hline $\begin{array}{l}\text { Socio Economic Status } \\
\text { - Low } \\
\text { - Moderate } \\
\text { - High }\end{array}$ & $\begin{array}{l}6 \\
82 \\
45\end{array}$ & $\begin{array}{l}4.5 \\
61.7 \\
33.8 \\
\end{array}$ & $\begin{array}{l}9 \\
136 \\
130\end{array}$ & $\begin{array}{l}3.3 \\
49.5 \\
47.3\end{array}$ & 6.65 & $0.036^{*}$ \\
\hline $\begin{array}{ll}\text { - } & \text { Knowledge } \\
\text { - } & \text { Appropriate }(\geq 60 \%) \\
\text { - } & \text { Inappropriate }(<60 \%)\end{array}$ & $\begin{array}{l}102 \\
31\end{array}$ & $\begin{array}{l}76.7 \\
23.3\end{array}$ & $\begin{array}{l}212 \\
63\end{array}$ & $\begin{array}{l}77.1 \\
22.9\end{array}$ & 0.008 & 0.93 \\
\hline $\begin{array}{l}\text { Practice } \\
\text { - Appropriate }(\geq 60 \%) \\
\text { - Inappropriate }(<60 \%)\end{array}$ & $\begin{array}{l}19 \\
114\end{array}$ & $\begin{array}{l}14.3 \\
85.7\end{array}$ & $\begin{array}{l}42 \\
233\end{array}$ & $\begin{array}{l}15.3 \\
84.7\end{array}$ & 0.07 & 0.79 \\
\hline
\end{tabular}


Table (5): Comparison of oral hygiene practice with regarding socio demographic character of the studied group

\begin{tabular}{|c|c|c|c|c|c|c|}
\hline \multirow{2}{*}{$\begin{array}{l}\text { Practice } \\
\begin{array}{ll}\text { Sex } & \\
\text { - Male } \\
\text { - Female }\end{array}\end{array}$} & \multicolumn{2}{|c|}{$\begin{array}{l}\text { Appropriate } \\
(\geq 60 \%) \\
(61)\end{array}$} & \multicolumn{2}{|c|}{$\begin{array}{l}\text { Inappropriate } \\
(<60 \%) \\
(347)\end{array}$} & \multirow{2}{*}{$\begin{array}{l}\text { Statistical } \\
\text { test } \\
X^{2} \\
14.05\end{array}$} & \multirow{2}{*}{$\begin{array}{l}\text { P value } \\
<0.001 *\end{array}$} \\
\hline & $\begin{array}{l}17 \\
44\end{array}$ & $\begin{array}{l}27.9 \\
72.1\end{array}$ & $\begin{array}{l}187 \\
160\end{array}$ & $\begin{array}{l}53.9 \\
46.1\end{array}$ & & \\
\hline $\begin{array}{l}\text { Age of mother } \\
\text { - mean } \pm \mathrm{SD}\end{array}$ & \multicolumn{2}{|c|}{$36.61 \pm 5.53$} & \multicolumn{2}{|c|}{$37.33 \pm 5.29$} & $\begin{array}{l}\mathrm{t} \mathrm{test}^{* *} \\
0.97\end{array}$ & 0.33 \\
\hline $\begin{array}{c}\text { Age of student } \\
\text { - mean } \pm \mathrm{SD}\end{array}$ & \multicolumn{2}{|c|}{$9.87 \pm 0.78$} & \multicolumn{2}{|c|}{$10.03 \pm 0.86$} & $\begin{array}{l}\mathrm{t} \text { test } \\
1.4\end{array}$ & 0.16 \\
\hline $\begin{array}{l}\text { SES levels n }(\%) \\
\text { - Low } \\
\text { - Moderate } \\
\text { - High }\end{array}$ & $\begin{array}{l}2 \\
30 \\
29\end{array}$ & $\begin{array}{l}3.3 \\
49.2 \\
47.5\end{array}$ & $\begin{array}{l}13 \\
188 \\
146\end{array}$ & $\begin{array}{l}3.7 \\
54.2 \\
42.1\end{array}$ & 0.64 & 0.73 \\
\hline $\begin{array}{l}\text { Level of mother } \\
\text { education } \\
\text { - Illiterate } \\
\text { - Primary } \\
\text { - } \text { preparatory } \\
\text { - Secondary } \\
\text { - University }\end{array}$ & $\begin{array}{l}1 \\
11 \\
27 \\
22\end{array}$ & $\begin{array}{l}1.6 \\
18.0 \\
44.3 \\
36.1\end{array}$ & $\begin{array}{l}11 \\
68 \\
117 \\
151\end{array}$ & $\begin{array}{l}3.2 \\
19.6 \\
33.7 \\
43.5\end{array}$ & 2.79 & 0.43 \\
\hline $\begin{array}{l}\text { Level of father } \\
\text { education } \\
\text { - Illiterate } \\
\text { - Primary/ } \\
\text { preparatory } \\
\text { - Secondary } \\
\text { - University } \\
\end{array}$ & $\begin{array}{l}1 \\
9 \\
20 \\
31\end{array}$ & $\begin{array}{l}1.6 \\
14.8 \\
32.8 \\
50.8\end{array}$ & $\begin{array}{l}12 \\
58 \\
107 \\
170\end{array}$ & $\begin{array}{l}3.5 \\
16.7 \\
30.8 \\
49.0\end{array}$ & 0.76 & 0.86 \\
\hline $\begin{array}{l}\text { Mother's Job } \\
\text { - House wife } \\
\text { - Un employer } \\
\text { - Employer } \\
\text { - } \text { Professional } \\
\end{array}$ & $\begin{array}{l}32 \\
3 \\
7 \\
19 \\
\end{array}$ & $\begin{array}{l}52.5 \\
4.9 \\
11.5 \\
31.1 \\
\end{array}$ & $\begin{array}{l}198 \\
12 \\
28 \\
109 \\
\end{array}$ & $\begin{array}{l}57.1 \\
3.5 \\
8.1 \\
31.4 \\
\end{array}$ & 1.19 & 0.75 \\
\hline $\begin{array}{c}\text { Father's Job } \\
\text { - Un employer } \\
\text { - Employer } \\
\text { - Professional }\end{array}$ & $\begin{array}{l}12 \\
19 \\
30 \\
\end{array}$ & $\begin{array}{l}19.9 \\
31.1 \\
49 \\
\end{array}$ & $\begin{array}{l}74 \\
75 \\
198 \\
\end{array}$ & $\begin{array}{l}21.3 \\
21.6 \\
57.1 \\
\end{array}$ & 2.69 & 0.26 \\
\hline
\end{tabular}




\section{الملخص العربي}

\section{صحة الفم والأسنان في أطفال المدارس الابتدائية بمركز بنها ـ محافظة القليوبيةـ مصر}

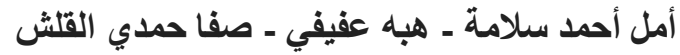
الخلفية: لوحظ زيادة نسبة تسوس الأسنان لدى الأطفال و المر اهقين في البلدان النامية مقارنة بالبلدان المتقدمة خلال العقدين الماضيين. لا يُعرف الكثير عن اتجاهات وسلوكيات صحة الفم لدى الأطفال من البلدان النامية.الهذف: تهدف هذه الدراسة الى تقييم صحة الفم والأسنان لأطفال المدارس الابتدائية في مركز بنها بمحافظة القليوبية. المشاركين وطرق البحث: في دراسة مقطعية ، نم عمل مسح لمجمو عه مكونة من 408 طفل في سن 9-11 سنة باستخدام استبيان منظم ذاتيًا مكتوب باللغة العربية وتم تطبيق هذا الاستبيان عليهم وكان يتضمن تحديد بياناتهم الاجتماعية والديمو غر افية تقييم ممارسة أطفال فيما يتعلق بصحة الفم والأسنان. بالإضافة إلى ذلك ، تعرض الأطفال أيضًا لفحص الفم التي أجريت في لإني العيادة المدرسية من قِبل الباحث و طبيب الاسنان. النتائج: كان عمر المجموعة المدروسة 9-11 سنة مع متوسط العمر 0,85_10,01 و التلاميذ الذكوريمثلون نصف حجم العينة . متوسط عمر الأمهات 37,22 + 5,32 سنة. كانت الوظائف المهنية تمثل 30,4\% لاى الاباء. وكانت غالبية الأمهات ربات منزل53.9 ٪. كانت نسبة الأسر التي تضم اكثر من خمسة افراد تمثل 74.5 ٪. كان متوسط دخل الأسرة في الثهر كافيًا لدى 63\%من الاسر وكان مؤشر الازدحام أقل من ثلاثة اشخاص بالغرفة الواحدة يمثل 70.3٪. غالبية الطلاب كانوا يفهمون المعلومات الصحية من خلال المعلومات المكتوبة 67.2 ٪و اظهرت الدر اسة ان 67.6 ٪ من الطلاب مصابين بتسوس

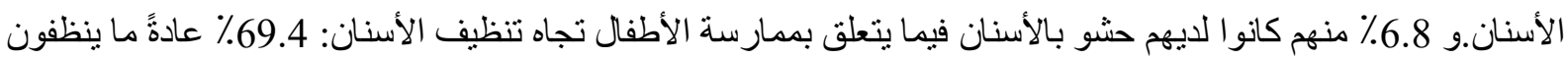
أسنانهم ، 65.7٪ ينظفون أسنانهم مرتين أو أكثر في اليوم ، 99.6٪ يستخدمون فرشاة الأسنان ومعجون الأسنان لتنظيف الأسنان ، 74.9٪ أسنانهم في الصباح ,39.9 \% يقو مون بتنظيف أسنانهم لأكثر من دقيقتين وأولياء الأمور لا يشاهدون الطفل ولكن يكتفوا بتقديم المشورة فقط وفقا لما أقر 68.1 ٪ من الاطفال وكانت هنالك فروق ذات دلالة إحصائية بين حالة صحة الفم لدى الأطفال و عمر الطلاب حيثز ادت نسبة تسوس الأسنان مع السن الاصغر في المجموعة التي شملتها الدراسة (9.93 10.86) ، وبين الطلاب ذوي الحالة الاقتصادية المرتفعة و المتوسطة و الذين لديهم امهات متعلمات , كان هنالك فروق ذات دلالة إحصائية بين ممارسة الأطفال حيث أن الطالبات كن يمارسن تنظيف الأسنان أكثر من الذكور. الخلاصة: ممارسة الأطفال فيما يتعلق بتنظيف الأسنان غير كافية وتحتاج إلى تعزيز ـ زيادة نسبة تسوس الأسنان بين الأطفال

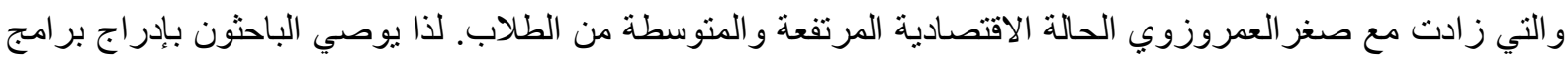
تدريبية لطلاب المدارس لتحسين ممارسة العناية بصحة الفم و الاسنان على نطاق أوسع و عمل فحص دوري لاطفال المدارس. 